\title{
Relative Efficiency of Two Bottom Trawls in Catching Juvenile and Commercial-sized Flatfishes in the Gulf of St. Lawrence
}

\author{
S. J. Walsh \\ Department of Fisheries and Oceans, Fisheries Research Branch \\ Northwest Atlantic Fisheries Centre, P. O. Box 5667 \\ St. John's, Newfoundland, Canada A1C 5X1
}

\begin{abstract}
The relative efficiencies of a No. 36 Yankee shrimp trawl and a No. 41.5 Yankee otter trawl in catching three species of flatfishes (witch flounder, American plaice and Greenland halibut) were compared from data collected during research-vessel surveys of the northeastern Gulf of St. Lawrence. The shrimp trawl outfished the otter trawl in catching juveniles $(<30 \mathrm{~cm})$ of the three species, the greatest differences being for witch flounder and American plaice. The performance of the shrimp trawl, without and with a tickler chain attached to the footrope, in catching juvenile and commercial-sized $(\geqslant 30 \mathrm{~cm})$ flatfishes was evaluated from a series of replicate tows. Marked increases in the catches of juveniles were observed for witch flounder and American plaice but not for Greenland halibut with the use of a tickler chain.
\end{abstract}

\section{Introduction}

In studies of factors that affect recruitment of marine fishes, there tends to be little emphasis on the juvenile stage (Bakun and Parrish, MS 1980), primarily because of difficulties in sampling (Lilly and Gavaris, 1982). Studies on juvenile flatfishes by European scientists involve the use of beam trawls, equipped with one or more tickler chains. Such trawls are used for both research and commercial purposes in the North Sea (including Wadden Sea) and the Irish Sea and for research surveys off the Oregon coast of the United States (Corlett, MS 1966; Kuipers, 1975; Riley, MS 1977; Pearcy, 1978). The rough bottom topography in most areas of the Northwest Atlantic limits the usefulness of beam trawls which operate efficiently on smooth bottom.

Little information has been published on the success of various trawling gears, except beam trawls, in sampling juvenile flatfish populations. Powles and Kohler (1970) reported some data on depth distribution of juvenile witch flounder (Glyptocephalus cynoglossus) on the Scotian Shelf and in the Gulf of St. Lawrence, derived from shrimp surveys with a Norwegian deepsea shrimp trawl. Pitt (1970) reported that no age 1 or age 2 yellowtail flounder (Limanda ferruginea), were found in surveys of the Grand Bank with a No. 41.5 Yankee otter trawl. Young witch flounder were found by Markle (1975) to be abundant on the continental slope off Virginia, from surveys with a No. 41.5 semiballoon trawl. Walsh (1982) reported good catches of juvenile (10-29 cm) American plaice (Hippoglossoides platessoides) on the Grand Bank with a No. 41.5 Yankee otter trawl. Tremblay (MS 1982) reported good catches of ages 1 and 2 Greenland halibut (Reinhardtius hippoglossoides) in the Gulf of St. Lawrence estuary from surveys with a 80/104 shrimp trawl. Except possibly for the shrimp trawls with $38 \mathrm{~mm}$ mesh size throughout, these trawls for research purposes were usually equipped with a small-mesh liner in the codend.

Surveys of the Gulf of St. Lawrence by research vessels of the Northwest Atlantic Fisheries Centre, St. John's, Newfoundland, have been conducted for several years with a No. 41.5 Yankee otter trawl, but these have yielded small catches of juvenile flatfishes. A survey of the northeastern part of the Gulf was conducted in 1980 with a No. 36 Yankee shrimp trawl, and the results from that survey are compared with those from three surveys with the No. 41.5 Yankee otter trawl in 1978-80, in order to determine if the former is effective enough to be used for young flatfish surveys on a regular basis. The performance of the No. 36 shrimp trawl was further evaluated from a series of replicate tows with and without a tickler chain. This experiment is part of a larger study to evaluate an efficient trawling gear for surveying juvenile flatfish populations off eastern Canada.

\section{Materials and Methods}

The surveys in 1978-80 by the research vessel $A . T$. Cameron (side trawler) were conducted with a standard No. 41.5 Yankee otter trawl constructed of polypropelene netting, with mesh size of $127 \mathrm{~mm}$ (stretched) in the wings reducing to $111 \mathrm{~mm}$ in the codend which contained a $30 \mathrm{~mm}$ mesh nylon liner. 
TABLE 1. Specifications of footgear in the trawls used during surveys for flatfishes in the eastern Gulf of St. Lawrence.

\begin{tabular}{lll}
\hline $\begin{array}{l}\text { Footrope } \\
\text { section }\end{array}$ & \multicolumn{1}{c}{$\begin{array}{c}\text { A. T. Cameron } \\
\text { No. } 41.5 \text { Yankee Otter Trawl }\end{array}$} & \multicolumn{1}{c}{$\begin{array}{c}\text { M. V. Zagreb } \\
\text { No. } 36 \text { Yanke Shrimp Trawl }\end{array}$} \\
\hline $\begin{array}{l}\text { Footrope } \\
\text { Wings }\end{array}$ & $\begin{array}{l}\text { Total length } 30 \mathrm{~m} . \\
\text { Two } 4.2 \mathrm{~m} \text { of manila-bound wire with one } 45.7 \\
\text { cm half-egg rubber bunt; two } 2.1 \mathrm{~m} \text { of } 2.2 \mathrm{~cm} \\
\text { wire with rubber discs and one } 45.7 \mathrm{~cm} \text { half- } \\
\text { egg rubber bunt. }\end{array}$ & $\begin{array}{l}\text { Total length } 24 \mathrm{~m} . \\
\text { Two } 10.4 \mathrm{~m} \text { of } 1.6 \mathrm{~cm} \text { wire with } 90.9 \mathrm{~kg} \text { of } 11.4 \\
\mathrm{~cm} \text { rubber discs. }\end{array}$ \\
Bunts & $\begin{array}{l}\text { Two } 1.7 \mathrm{~m} \text { of } 2.2 \mathrm{~cm} \text { wire with combination } \\
12.7 \times 20.3 \mathrm{~cm} \text { iron and rubber spacers and } \\
\text { one } 45.7 \mathrm{~cm} \text { half-egg rubber bunt. }\end{array}$ & Not designated (see Fig. 1). \\
Bosom & $\begin{array}{l}\text { One } 6 \mathrm{~m} 2.2 \mathrm{~cm} \text { wire with combination } 12.7 \\
\times 20.3 \mathrm{~cm} \text { iron and rubber spacers and eleven } \\
53.3 \mathrm{~cm} \text { rubber rollers. }\end{array}$ & $\begin{array}{l}\text { One } 3.3 \mathrm{~m} \text { of } 1.6 \mathrm{~cm} \text { wire with sixteen } 17.2 \times \\
17.8 \mathrm{~cm} \text { rubber spacers and two } 35.6 \mathrm{~cm} \\
\text { half-egg rubber bunts at each end. }\end{array}$ \\
Danlenos & $\begin{array}{l}\text { A } 53.3 \mathrm{~cm} \text { danleno and butterfly assembly are } \\
\text { used on each side between the forward end of } \\
\text { the footrope and the groundrope. }\end{array}$ & $\begin{array}{l}\text { A } 45.7 \mathrm{~cm} \text { danleno ball and butterfly assem- } \\
\text { bly are used on each side between the for- } \\
\text { ward end of the footrope and the ground- } \\
\text { rope. }\end{array}$ \\
\hline
\end{tabular}

The $30 \mathrm{~m}$ wire footrope contained eight half-egg rubber bunts between which were rubber rollers in the wing section, iron and rubber spacers in the bunt section and alternating rubber rollers and iron and rubber spacers in the bosum (Table 1, Fig. 1). The No. 36 Yankee shrimp trawl, which was used by the chartered stern trawler Zagreb in 1980, was constructed of 38.1 $\mathrm{mm}$ mesh polypropelene netting throughout and had a $12.7 \mathrm{~mm}$ mesh nylon liner in the codend. The $24 \mathrm{~m}$ wire footrope contained two half-egg rubber bunts between between which were rubber rollers in the wing section and rubber spacers in the bosum. Both trawls were equipped with danleno balls and butterfly assembly. Both vessels maintained a towing speed of 3.5 knots $(108 \mathrm{~m} / \mathrm{sec}$ ) and tow duration of $30 \mathrm{~min}$ at each fishing station.

The survey by the Zagreb in September 1980 consisted of fishing at a series of stations on five preselected line transects in NAFO Div. 4R off western Newfoundland (Fig. 2). Areas shallower than 100 fath $(183 \mathrm{~m})$ were not fished because of rough bottom or the presence of inshore fishing gear. Data from 48 successful sets were used in the analysis, 28 sets without tickler chain and 20 replicate sets with the chain attached to the trawl. The replicates involved making a set without the tickler chain and making another set at the same station $24 \mathrm{hr}$ later with the chain, ensuring that all towing characteristics (speed, duration, direction, depth, etc.) were maintained. Analysis of the data from these replicates involved certain assumptions in relation to the fishing strategy: (a) the density of flatfish at each station remained unchanged from one tow to the other one $24 \mathrm{hr}$ later; (b) extraneous factors, such as current, wind and bottom temperature remained unchanged during the 24-hr interval and thus did not affect the catch; and (c) patterns of diurnal movement remained the same for both riggings of the gear.

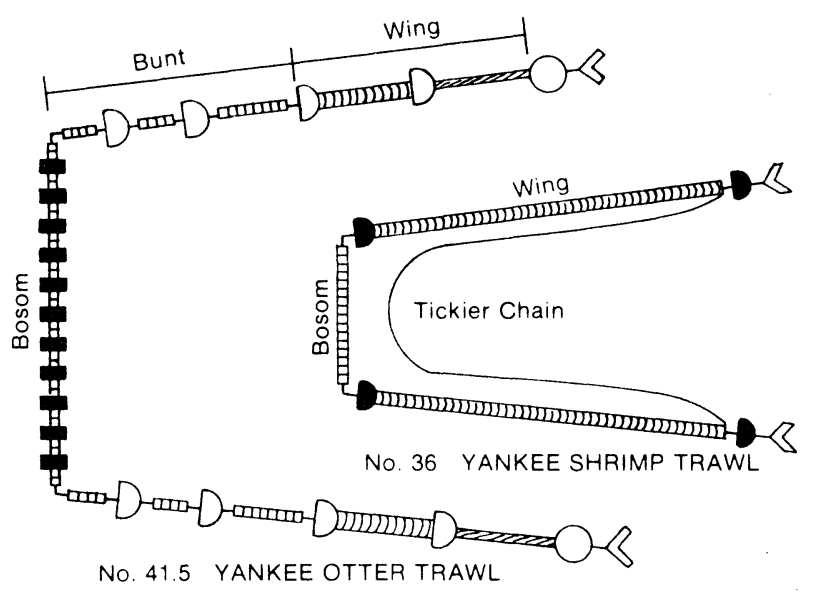

Fig. 1. Schematic diagrams of the footrope riggings of the No. 41.5 Yankee otter trawl and the No. 36 Yankee shrimp trawl used for surveys by the A. T. Cameron and Zagreb.

The flatfishes involved in this study are American plaice and witch flounder, which were measured as total length, and Greenland halibut, which were measured as fork length, all measurements being recorded to the nearest centimeter. The data were subsequently grouped by $2-\mathrm{cm}$ intervals for analysis. Catches of each species at each station were divided into two size categories, juveniles or prerecruits $(<30 \mathrm{~cm}$ long) and commercial-sized fish $(\geqslant 30 \mathrm{~cm})$, and these were logarithmically transformed, as proposed by Parrish (1951) and Taylor (1953), by the equation $\mathrm{Y}=\ln (\mathrm{N}+1)$, where $\mathrm{N}$ is the number of fish. This technique minimizes skewness in the distribution due to occasional large catches and accommodates "zero" catches. A onetailed t-test for paired (dependent) samples (Sokal and Rohlf, 1969) was used to test for significant differences $(P<0.05)$ in the catches at each fishing station with and without the use of tickler chain during the replicate tows. 


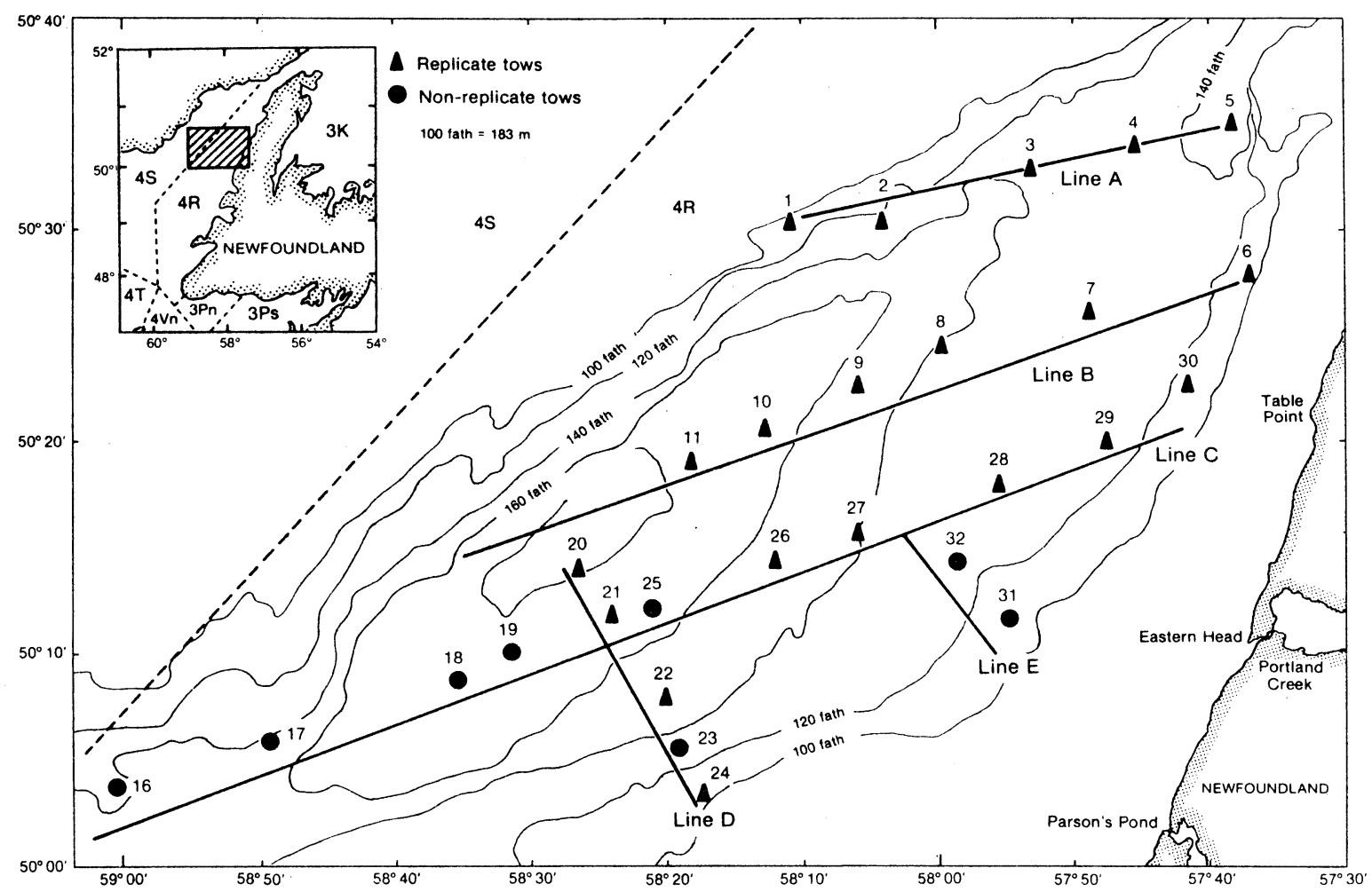

Fig. 2. Locations of stations fished with the No. 36 Yankee shrimp trawl during the Zagreb survey in September 1980.

For comparison with data from the 1980 fixedstation survey with the shrimp trawl (without tickler chain), catches and length frequencies of the three flatfish species from three stratified-random trawl surveys in Div. $4 R$ by the A. T. Cameron in October 1978 (34 sets), September-October 1979 (33 sets) and September 1980 ( 25 sets) were utilized. The comparative study also used $A$. T. Cameron survey data from sets north of $50^{\circ} \mathrm{N}$ in Div. 4R (i.e. data from 13,11 and 8 sets in 1978,1979 and 1980 respectively).

\section{Results}

\section{Comparison of shrimp trawl and otter trawl catches}

The length distributions of witch flounder, American plaice and Greenland halibut from the survey in 1980 with the No. 36 Yankee shrimp trawl (without tickler chain) were compared with those of the same species from surveys in 1978, 1979 and 1980 with the No. 41.5 Yankee otter trawl (Fig. 3-5). Although the length distributions from the latter surveys in the whole of Div. 4R are illustrated in the bottom panels of the figures, those for the area north of $50^{\circ} \mathrm{N}$ latitude are considered to be more comparable to results from the 1980 survey with the shrimp trawl.

Juvenile witch flounder were dominant in the shrimp-trawl catch, the majority of the fish being less than $20 \mathrm{~cm}$ in length (Fig. 3). The mean catch-per-tow of larger fish decreased with increasing length of fish. The otter-trawl catches showed the opposite trend with fish larger than $30 \mathrm{~cm}$ being the dominant group not only in the eastern Gulf of St. Lawrence area as a whole but also in the area north of $50^{\circ} \mathrm{N}$ where the shrimp trawl was also used. Although the catch index varied from year to year, it is evident from the length distributions that the same size-groups were sampled by the otter trawl during the 1978-80 surveys.

The length composition of the shrimp-trawl catch of American plaice was similar to that of witch flounder in that juveniles $(<20 \mathrm{~cm})$ were dominant and the catch-per-tow of larger fish decreased with increasing size (Fig. 4). The length distributions of otter-trawl catches in 1978-80 consisted of both juvenile and commercial-sized American plaice, the majority of the fish being in the size range of $18-38 \mathrm{~cm}$. This trend was consistent for the area north of $50^{\circ} \mathrm{N}$ as well as for the entire eastern Gulf area which involved about three times as many sets. Although both trawls sampled juveniles, the shrimp trawl appeared to be very efficient in catching American plaice less than $20 \mathrm{~cm}$ in length.

The length distributions of Greenland halibut in the catches with both trawls varied considerably, due possibly to the relatively low abundance of this species in the survey area, as inferred from the very low catch rates (Fig. 5). However, the shrimp trawl caught many more small juveniles $(<16 \mathrm{~cm})$ than the otter trawl. 


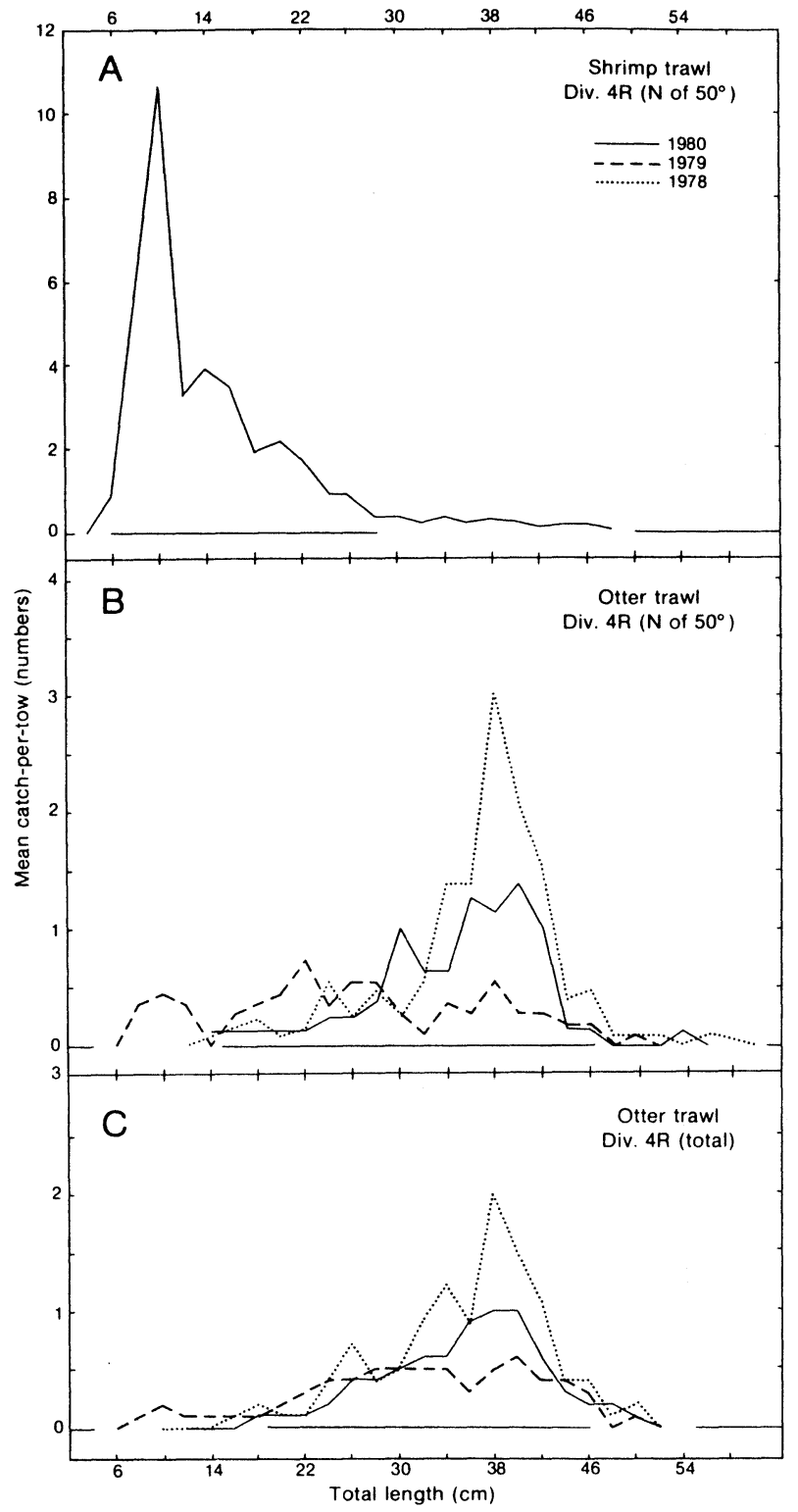

Fig. 3. Length distributions of witch flounder catches from surveys with the shrimp trawl north of $50^{\circ} \mathrm{N}$ in 1980 and with the otter trawl north of $50^{\circ} \mathrm{N}$ and in the whole of Div. 4R in 1978-80.

It is evident, therefore, that the shrimp trawl yielded larger catches of juveniles of the three species of flatfishes than the otter trawl, with the differences being greatest for witch flounder and smallest for Greenland halibut. These differences are clearly evident when only the length distributions for 1980 are examined, considering that the shrimp-trawl and otter trawl surveys were made about the same time of the year.

\section{Shrimp trawl catches with and without tickler chain}

Analysis of the data from the replicate-tow experiment, involving 20 tows without the tickler chain and 20 tows with the chain attached to the footgear of the

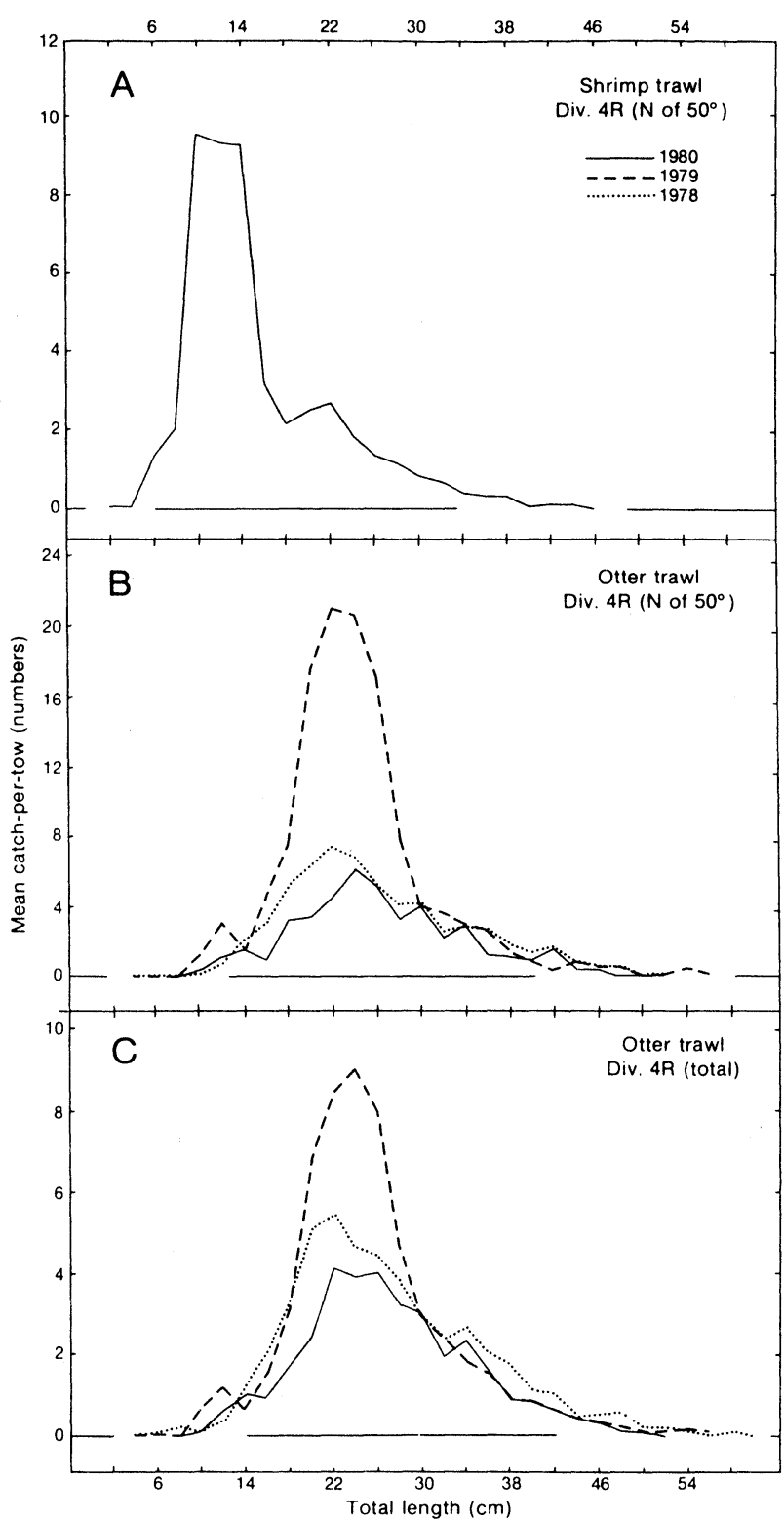

Fig. 4. Length distributions of American plaice catches from surveys with the shrimp trawl north of $50^{\circ} \mathrm{N}$ in 1980 and with the otter trawl north of $50^{\circ} \mathrm{N}$ and in the whole of Div. 4R in 1978-80.

shrimp trawl, indicated that significantly more $(P<0.01)$ witch flounder of both size categories were caught when the tickler chain was used (Table 2). Although substantially more American plaice of both size groups were caught when the tickler chain was used, differences were not significant except perhaps for the total catches $(P=0.05)$. Catches of Greenland halibut were very small and showed no difference with and without the use of the chain.

The relative size compositions of the catches with and without use of the chain did not differ greatly for all three species (Fig. 6). The most notable differences were increased catch of juvenile witch flounder $1<20$ 


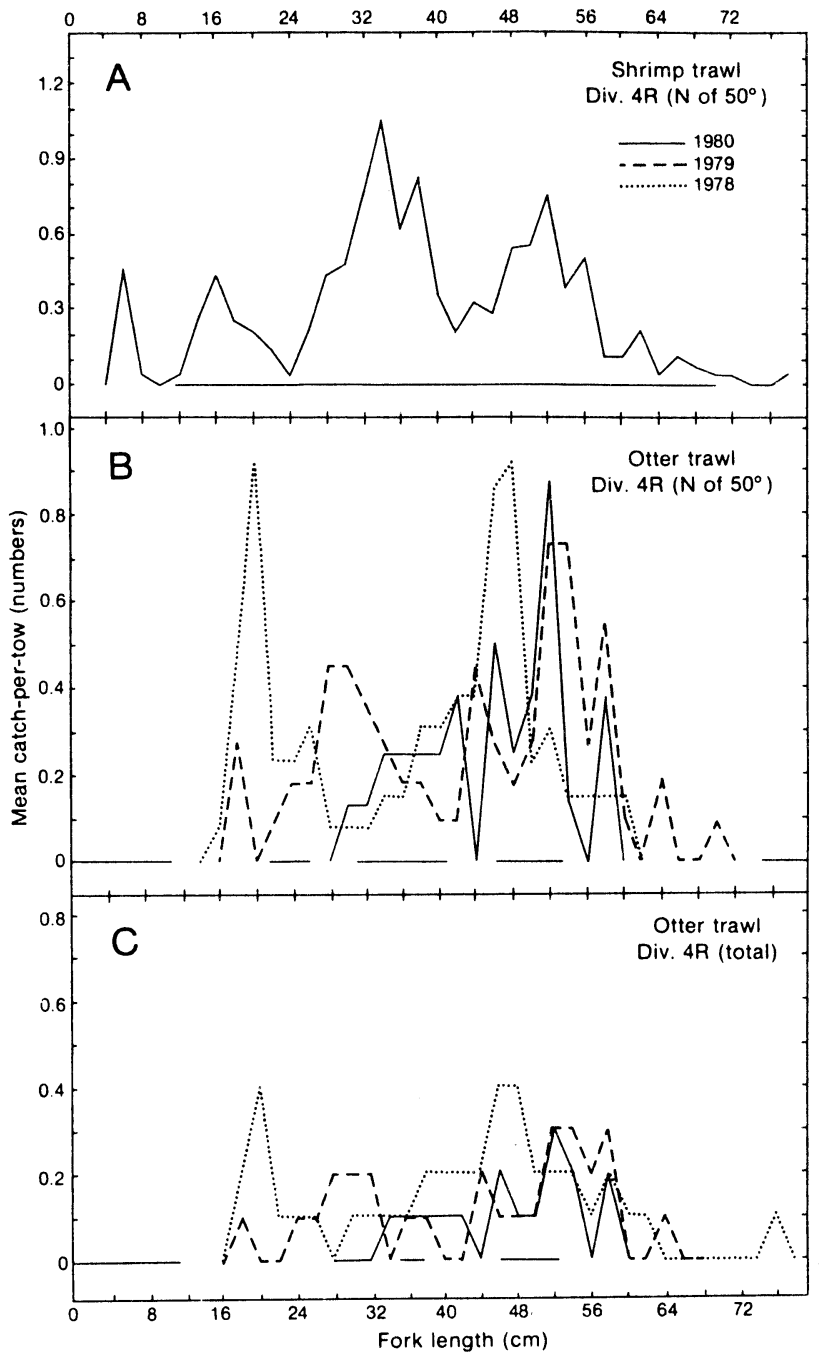

Fig. 5. Length distributions of Greenland halibut catches from surveys with the shrimp trawi north of $50^{\circ} \mathrm{N}$ in 1980 and with the otter trawl north of $50^{\circ} \mathrm{N}$ and in the whole of Div. $4 \mathrm{R}$ in 1978-80. $\mathrm{cm})$ and American plaice $(18-30 \mathrm{~cm})$ and somewhat lower numbers of Greenland halibut when the tickler chain was used.

\section{Discussion}

The greater efficiency of the shrimp trawl than the otter trawl in catching juvenile $(<30 \mathrm{~cm})$ flatfishes, especially witch flounder and American plaice, may in part be due to the differences in mesh size. Although escapement through the codend meshes is virtually eliminated by the use of small-mesh liners in both trawls, escapement through the larger meshes $(111-127 \mathrm{~mm})$ in the forward parts of the otter trawl may be much greater than through the smaller meshes (38 $\mathrm{mm}$ throughout) of the shrimp trawl. Pereyra et al. (1967), in their comparison of the relative efficiencies of a $70-\mathrm{ft}(21.3 \mathrm{~m})$ semiballoon shrimp trawl and a94-ft $(28.7 \mathrm{~m})$ eastern fish trawl, recognized the selective advantage of the shrimp trawl in retaining small fish and invertebrates and concluded that considerable escapement occurred through the larger meshes of the fish trawl. The success of small-mesh trawls in catching juvenile flatfishes was documented also by Powles and Kohler (1970), Markle (1975) and Tremblay (MS 1982).

Of greater significance in causing the shrimp trawl to yield considerably larger catches of juvenile flatfishes than the otter trawl may be the difference in footgear rigging. The absence of large bobbin-type rollers on the footrope of the shrimp trawl enables it to operate closer to the bottom and cause greater disturbance of the substratum. This was clearly evident for the shrimp trawl by the frequent occurrence, in the codend, of mud, which increased with the use of the tickler chain. Most of the sets by both vessels were made on muddy and sandy bottom, which are the kinds

TABLE 2. Comparison of flatfish catches in the shrimp trawl with and without tickler chains attached to the footrope, using paired $t$-tests on the log-transformed $(Y=\ln (\mathrm{N}+1))$ catches listed in the Appendix. $\left(S E=\right.$ standard error; * and ${ }^{*}$ indicate significance at $P=0.05$ and $P=0.01$ respectively; $N S=$ not significant.

\begin{tabular}{|c|c|c|c|c|c|c|}
\hline \multirow[b]{2}{*}{ Species } & \multirow{2}{*}{$\begin{array}{c}\text { Size } \\
\text { category }\end{array}$} & \multicolumn{2}{|c|}{ Total number caught } & \multicolumn{3}{|c|}{$\begin{array}{l}\text { Paired t-test results from } \\
\text { log-transformed catches }\end{array}$} \\
\hline & & chain & chain & Mean $\triangle$ & SE & Sign \\
\hline \multirow[t]{3}{*}{ Witch flounder } & $<30 \mathrm{~cm}$ & 3,241 & 675 & 1.72 & 0.205 & "* \\
\hline & $\geqslant 30 \mathrm{~cm}$ & 105 & 39 & 0.74 & 0.138 & ** \\
\hline & Total & 3,346 & 714 & 1.70 & 0.199 & ** \\
\hline \multirow[t]{3}{*}{ American plaice } & $<30 \mathrm{~cm}$ & 1,727 & 1,089 & 0.32 & 0.191 & NS \\
\hline & $\geqslant 30 \mathrm{~cm}$ & 107 & 65 & 0.34 & 0.214 & NS \\
\hline & Total & 1,834 & 1,154 & 0.42 & 0.200 & * \\
\hline \multirow[t]{3}{*}{ Greenland halibut } & $<30 \mathrm{~cm}$ & 30 & 59 & -0.15 & 0.165 & NS \\
\hline & $\geqslant 30 \mathrm{~cm}$ & 205 & 179 & -0.31 & 0.205 & NS \\
\hline & Total & 235 & 238 & -0.39 & 0.198 & NS \\
\hline
\end{tabular}




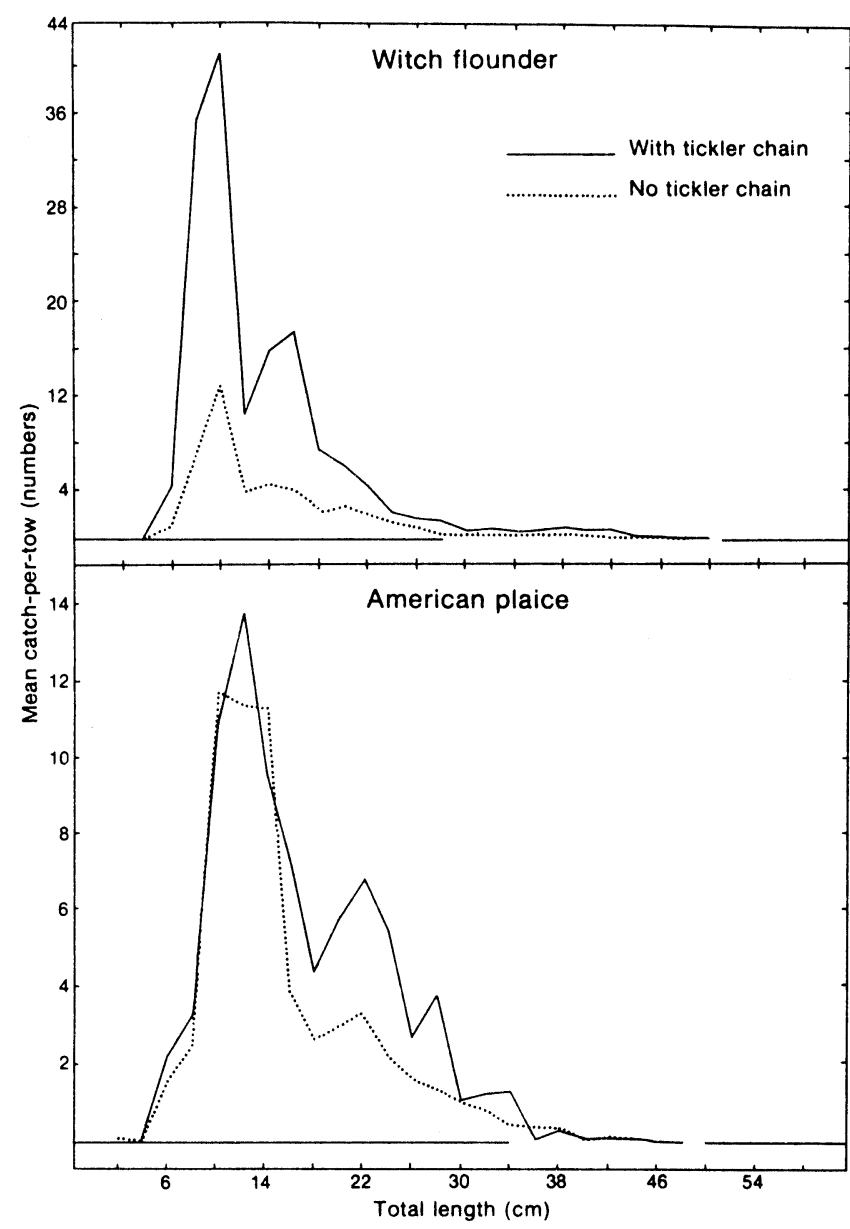

of substrata preferred by witch flounder and American plaice (Bigelow and Schroeder, 1953; Leim and Scott, 1966). The towing of the trawl with a tickler chain in contact with the seabed causes considerable disturbance of the bottom sediments in front of the footrope, with the result that small flatfish lying on or buried in the sediments are routed out and are less likely to escape under the footrope of the trawl. The relative catch rates of small and large witch flounder in the No. 36 Yankee shrimp trawl with tickler chain were similar to those obtained by Markle (1975) in a No. 41.5 semiballoon trawl (38 $\mathrm{mm}$ mesh throughout) with no disc rollers or bobbins on the footrope but with a tickler chain hung loop-style from it.

Literature on the use of tickler chains and their effects on catching efficiency of otter trawls is sparse. Parrish (1951), from a comparative study of the efficiency of two different otter trawls used by two British research vessels (both trawls being operated with and without tickler chains), concluded that, without tickler chain, the heavier of the two trawls outfished the other for European plaice (Pleuronectes platessa) and common dab (Limanda limanda), but that the catching efficiencies of the two trawls were about the same for both species when tickler chains were used. HardenJones and Scholes (1974) reported that the use of door-to-door tickler chains on commercial otter trawls

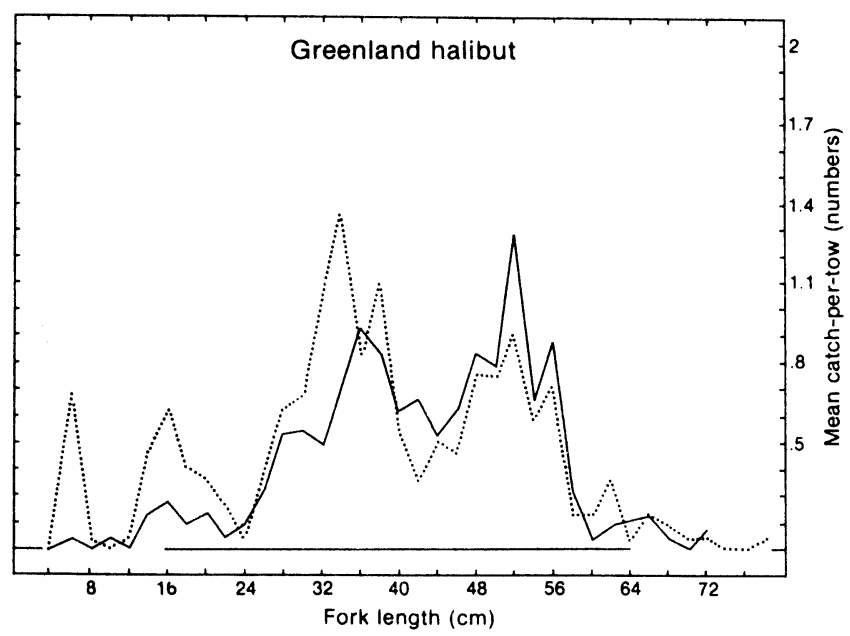

Fig. 6. Length distributions of catches of witch flounder, American plaice and Greenland halibut north of $50^{\circ} \mathrm{N}$ in Div. 4R, from the 1980 shrimp trawl survey with and without the use of tickler chain.

increased the catch rate of European plaice by a factor of 2 to 3 . From the present study, catch rates of both juvenile and adult witch flounder were significantly higher and those of American plaice only marginally higher (but not significantly so) with the use of the tickler chain than without it. Use of the tickler chain had little effect on the catches of Greenland halibut, which tend to be more semipelagic than demersal.

In conclusion, the shrimp trawl caught more small flatfishes than the otter trawl, and the catch rates with the shrimp trawl were sufficiently high to encourage the use of this trawl for young-fish surveys involving witch flounder and American plaice. Catches of these species were further enhanced by the use of a tickler chain. The limitations on the use of the shrimp trawl, rigged as described above, are being tested on the rough bottom of the Grand Bank. Different footgear riggings are also being examined in an effort to overcome problems associated with the use of such trawls in areas of rough bottom.

\section{Acknowledgements}

I thank K. Mercer who assisted in tabulating the data, C. A. Rose for the illustrations, and J. T. Anderson and $G$. R. Lilly who reviewed the initial manuscript. 


\section{References}

BAKUN, A., and R. H. PARRISH. 1980. Environment inputs to fishery population models for eastern boundary current regions. In Workshop on the effects of environmental variation on the survival of larval pelagic fishes, G. D. Sharp (ed.), Intergovernmental Oceanographic Commission, UNESCO, Paris, Rep. No. 28, p. 67-104.

BIGELOW, H. B., and W. C. SCHROEDER. 1953. Fishes of the Gulf of Maine. Fish. Bull. U. S., 53, 577 p.

CORLETT, J. MS 1966. Mortality of 0-group plaice in the northern Irish Sea. ICES C. M. Doc., No. C:6, 8 p.

HARDEN-JONES, F. R., and P. SCHOLES. 1974. The effect of the door-to-door tickler chain on the catch rate of plaice (Pleuronectes platessa L.) taken by an otter trawl. ICES J. Cons., 35 210-212.

KUIPERS, B. 1975. On the efficiency of a two-metre beam trawl for juvenile plaice (Pleuronectes platessa). Neth. J. Sea Res., 9: 69-85.

LEIM, A. H., and W. B. SCOTT. 1966. Fishes of the Atlantic coast of Canada. Bull. Fish. Res. Board Can., 155, 485 p.

LILLY, G. R., and C. A. GAVARIS. 1982. Distribution and year-class strength of juvenile redfish, Sebastes sp., on Flemish Cap in the winters of 1978-82. J. Northw. Atl. Fish. Sci., 3: 115-122.

MARKLE, D.F. 1975. Young witch flounder, Glyptocephalus cynoglossus, on the slope off Virginia. J. Fish. Res. Board Can., 32: 14471450.

PARRISH, B. B. 1951. Fishing capacities of Lowestoft and Aberdeen trawls when used on flatfish grounds. ICES J. Cons., 17: 156-171.
PEARCY, W. G. 1978. Distribution and abundance of small flatfishes and other demersal fishes in a region of diverse sediments and bathymetry off Oregon. Fish. Bull. U.S., 76: 629-640.

PEREYRA, W. T., H. HEYAMOTO, and R. R. SIMPSON. 1967. Relative catching efficiency of a 70-foot semi-balloon shrimp trawl and a 94-foot eastern fish trawl. Fish. Ind. Res., 4(1): 49-71.

PITT, T. K. 1970. Distribution, abundance, and spawning of yellowtail flounder, Limanda ferruginea, in the Newfoundland area of the Northwest Atlantic. J. Fish. Res. Board Can., 27: 2261-2271.

POWLES, P. M., and A. C. KOHLER. 1970. Depth distributions of various stages of witch flounder, Glyptocephalus cynoglossus, off Nova Scotia and in the Gulf of St. Lawrence. J. Fish. Res. Board Can., 27: 2053-2062.

RILEY, J. D. MS 1977. On the evaluation of the English east coast 0-group flatfish year-class measurements, 1973-76. ICES C.M. Doc., No. F:25, 7 p.

SOKAL, R. R., and F. J. ROHLF. 1969. Biometry. W. H. Freeman and Co., San Francisco, $776 \mathrm{p}$

TAYLOR, C. C. 1953. Nature of variability in trawl catches. Fish. Bull. U.S., 54: 143-166.

TREMBLAY, C. MS 1982. Le fletan Groenland du Golfe du SaintLaurent (4RST): consequencies de son exploitation et evaluation de son recruitment. Can. Atl. Fish. Sci. Adv. Committee Res. Doc., No. $18,32 \mathrm{p}$.

WALSH, S. J. 1982. Distribution and abundance of prerecruit and commercial-sized American plaice on the Grand Bank. J. Northw. Atl. Fish. Sci., 3: 149-157. 


\section{Appendix}

Logarithms $(I n)$ of the numbers of three species of flatfishes caught in the shrimp trawl from 20 replicate tows in the northeastern Gulf of St. Lawrence in 1980.

\begin{tabular}{|c|c|c|c|c|c|}
\hline \multirow[b]{2}{*}{ Species } & \multirow[b]{2}{*}{$\begin{array}{c}\text { Station } \\
\text { No. }\end{array}$} & \multicolumn{2}{|c|}{ Juveniles } & \multicolumn{2}{|c|}{ Commercial } \\
\hline & & $\begin{array}{l}\text { without } \\
\text { chain }\end{array}$ & $\begin{array}{l}\text { with } \\
\text { chain }\end{array}$ & $\begin{array}{l}\text { without } \\
\text { chain }\end{array}$ & $\begin{array}{l}\text { with } \\
\text { chain }\end{array}$ \\
\hline Witch & $\mathrm{A} 01$ & 1.39 & 4.11 & 1.10 & 1.61 \\
\hline \multirow[t]{19}{*}{ flounder } & $\mathrm{A} 02$ & 3.00 & 3.85 & 0.69 & 1.10 \\
\hline & $\mathrm{A} 03$ & 3.56 & 6.42 & 1.10 & 1.95 \\
\hline & A04 & 3.53 & 4.58 & 0.00 & 0.00 \\
\hline & A05 & 5.35 & 6.75 & 2.77 & 3.37 \\
\hline & B06 & 3.91 & 4.65 & 1.79 & 3.30 \\
\hline & $\mathrm{B} 07$ & 3.93 & 3.93 & 0.00 & 0.00 \\
\hline & B08 & 2.40 & 4.64 & 0.00 & 1.10 \\
\hline & B09 & 2.83 & 4.85 & 0.00 & 1.79 \\
\hline & B10 & 2.48 & 4.96 & 0.00 & 2.08 \\
\hline & B11 & 0.00 & 3.78 & 0.00 & 0.69 \\
\hline & $\mathrm{C} 26$ & 2.40 & 4.84 & 1.10 & 1.61 \\
\hline & $\mathrm{C} 27$ & 3.22 & 4.83 & 0.00 & 1.39 \\
\hline & $\mathrm{C} 28$ & 3.69 & 4.87 & 0.69 & 1.39 \\
\hline & C29 & 4.22 & 5.95 & 1.39 & 2.30 \\
\hline & $\mathrm{C} 30$ & 3.97 & 4.30 & 0.00 & 1.10 \\
\hline & D20 & 2.20 & 3.40 & 0.00 & 0.69 \\
\hline & $\mathrm{D} 21$ & 2.49 & 4.19 & 1.10 & 1.10 \\
\hline & D22 & 2.48 & 4.22 & 0.00 & 0.00 \\
\hline & D24 & 0.00 & 2.20 & 0.00 & 0.00 \\
\hline \multirow{10}{*}{$\begin{array}{l}\text { American } \\
\text { plaice }\end{array}$} & A01 & 4.34 & 5.09 & 1.10 & 2.40 \\
\hline & A02 & 2.94 & 4.36 & 1.39 & 1.39 \\
\hline & $\mathrm{A} 03$ & 2.64 & 2.71 & 0.69 & 1.39 \\
\hline & $\mathrm{A} 04$ & 2.89 & 2.89 & 2.08 & 1.95 \\
\hline & A05 & 3.33 & 3.40 & 2.08 & 2.77 \\
\hline & B06 & 6.52 & 7.02 & 2.57 & 3.71 \\
\hline & B07 & 3.18 & 3.14 & 1.95 & 0.69 \\
\hline & B08 & 1.95 & 1.61 & 0.69 & 0.00 \\
\hline & B09 & 1.10 & 1.39 & 0.00 & 1.39 \\
\hline & B10 & 0.00 & 1.10 & 0.00 & 1.10 \\
\hline
\end{tabular}

\begin{tabular}{|c|c|c|c|c|c|}
\hline \multirow[b]{2}{*}{ Species } & \multirow[b]{2}{*}{$\begin{array}{c}\text { Station } \\
\text { No. }\end{array}$} & \multicolumn{2}{|c|}{ Juveniles } & \multicolumn{2}{|c|}{ Commercial } \\
\hline & & $\begin{array}{l}\text { without } \\
\text { chain }\end{array}$ & $\begin{array}{l}\text { with } \\
\text { chain }\end{array}$ & $\begin{array}{l}\text { without } \\
\text { chain }\end{array}$ & $\begin{array}{l}\text { with } \\
\text { chain }\end{array}$ \\
\hline \multirow{10}{*}{$\begin{array}{l}\text { American } \\
\text { plaice } \\
\text { (cont'd) }\end{array}$} & B11 & 0.00 & 1.79 & 0.00 & 0.00 \\
\hline & $\mathrm{C} 26$ & 1.39 & 2.64 & 0.00 & 1.10 \\
\hline & $\mathrm{C} 27$ & 1.95 & 2.08 & 0.00 & 1.10 \\
\hline & C28 & 2.30 & 2.89 & 1.10 & 1.39 \\
\hline & C29 & 3.85 & 4.01 & 1.39 & 1.39 \\
\hline & C30 & 4.61 & 5.14 & 2.64 & 1.95 \\
\hline & D20 & 1.61 & 1.79 & 0.00 & 1.10 \\
\hline & D21 & 1.10 & 1.10 & 0.00 & 1.61 \\
\hline & D22 & 1.61 & 1.95 & 1.10 & 1.10 \\
\hline & D24 & 4.08 & 1.61 & 1.95 & 0.00 \\
\hline \multirow{20}{*}{$\begin{array}{l}\text { Greenland } \\
\text { halibut }\end{array}$} & $\mathrm{A} 01$ & 0.00 & 0.69 & 0.69 & 0.00 \\
\hline & $\mathrm{A} 02$ & 0.00 & 0.69 & 1.61 & 2.64 \\
\hline & $\mathrm{A} 03$ & 0.00 & 0.00 & 2.89 & 2.40 \\
\hline & $\mathrm{A} 04$ & 2.64 & 1.79 & 2.71 & 2.48 \\
\hline & A05 & 3.22 & 1.79 & 2.56 & 3.87 \\
\hline & B06 & 0.69 & 0.00 & 1.79 & 0.00 \\
\hline & B07 & 1.79 & 2.20 & 2.40 & 1.79 \\
\hline & B08 & 0.00 & 0.00 & 1.61 & 1.61 \\
\hline & B09 & 0.00 & 0.00 & 2.83 & 1.10 \\
\hline & B10 & 0.69 & 0.00 & 2.40 & 1.61 \\
\hline & $\mathrm{B} 11$ & 0.69 & 0.00 & 3.00 & 2.30 \\
\hline & C26 & 0.69 & 0.69 & 1.79 & 2.08 \\
\hline & $\mathrm{C} 27$ & 0.00 & 0.00 & 2.08 & 0.00 \\
\hline & C28 & 1.61 & 0.69 & 1.79 & 2.40 \\
\hline & C29 & 0.00 & 0.00 & 2.08 & 1.61 \\
\hline & C30 & 0.00 & 0.00 & 1.61 & 1.10 \\
\hline & D20 & 0.00 & 0.00 & 3.04 & 4.14 \\
\hline & D21 & 0.00 & 1.61 & 2.40 & $2: 08$ \\
\hline & $\mathrm{D} 22$ & 1.10 & 1.39 & 2.30 & 2.20 \\
\hline & D24 & 2.08 & 0.69 & 0.00 & 0.00 \\
\hline
\end{tabular}

